KATARZYNA KRAWERENDA-WAJDA ${ }^{1}$

\title{
THE SPIRITUALITY OF CONTEMPORARY DANES - BETWEEN PAGANISM AND SECULARISATION
}

\begin{abstract}
The topic of the article is the issue of the place of religion in contemporary Danish society. Not only Scandinavia, but all of Europe is subject to secularisation processes. As a result of this process, the role of the Christian religion remains limited or eliminated. However this crisis of religion, does not affect the deeprooted desire for transcendence and individual search for it. In the case of Denmark, it appears in a return to neo-paganism - a reconstructionist religion that attempts to return to the religion of the "nature" of ancient and early medieval Germans. An example of this religion is the Ásatrú movement, dynamically developing in Denmark. On the other hand, the need for transcendence is realised by the phenomenon of spirituality, which is the need for self-transcending. Both of these directions are an expression of freedom, finding meaning, but also a conscious search for identity in a dynamically changing Europe.
\end{abstract}

Key words: spirituality, religion, Denmark, crisis of Christianity

\section{INTRODUCTION}

This article discusses the place of religion in contemporary Danish society, showing the forms in which the "need for transcendence" in human life is manifested. The crisis of Christianity and the departure from Lutheran Church do not imply, necessarily, resignation from the spiritual needs of every human being, but rather that these needs may manifest themselves in a desire to return to the origins of one's culture: in this case, sagas, Edda and religious rites practiced before the Christianisation of Scandinavia.

\footnotetext{
${ }^{1} \mathrm{PhD}$; Jagiellonian University in Kraków; e-mail: katarzynakrawerenda@gmail.com.
} 
To address the issue of religion in Denmark, we must first show how religiousness differs from spirituality. Religiousness is associated with an institution, its requirements, orthodox teaching, duties resulting from belonging to a specific community, and obligations towards Church and God. Spirituality, on the other hand, is a private religion, the spiritual involvement of a human being, independent of any institution. This phenomenon is referred to as "the new spirituality", and although it is not clearly defined, it can be understand intuitively. Below is an understanding of spirituality as proposed by Zbigniew Pasek:

We suggest calling the word "spirituality" these actions, attitudes and beliefs of man in which his pursuit of transgression is realised. This is understood in various ways to transcend his own temporal condition and current life situation. This process is done in the name of values, considered by the individual human to be positive, good (often these values are referred as summum bonum). We believe that these values can be religious as well as ethical, aesthetic, or other, unrelated to the sphere of religion. In this way, we emphasise the fact that the individual's involvement in these values, ideas and activities, perform similar functions to traditional religions, in that they provide sense, explain the world, and sometimes also satisfy the needs of belonging and acceptance. They answer the questions of "final concern" posed by Paul Tillich (Skowronek \& Pasek, 2013, pp. 18-19). ${ }^{2}$

It is worth emphasising that spirituality in the Christian tradition has been a synonym of religiosity or a more profound internal life, e.g. monasticism. "Spiritual" is what comes inspired by the Spirit, from within. According to Socha (2014, p. 24), this understanding of spirituality does not exclude the traditional form of religiosity and may mean a deepened dimension of religiousness. ${ }^{3}$ This paper now proceeds to present the relationship between these two concepts and how they refer to the individual existence of contemporary Danes.

${ }^{2}$ All translations come from the author of the article unless marked otherwise.

${ }^{3}$ According to the psychologist of religion, Paweł Socha, spirituality makes human existence beyond the material, carnal and temporary side of humanity. In this sense, one's spiritual nature is primordial in relation to one's innate nature. What in traditional religions is called the soul and what is eternal, it defines the character of a person (Socha, 2014, p. 24). 


\section{RELIGION IN DENMARK}

It seems that Danish religiosity and spirituality may be considered against two backdrops: one is the Lutheran Church, which is the state religion in Denmark, and the other is slowly resurging neo-paganism, i.e. the Asatran movement.

The Lutheran Church will be discussed first. With the Reformation in Denmark in 1536, Lutheran Christianity was established as the state religion. With the Constitution of 1849, Denmark introduced freedom of religion, although Lutheranism remained the established church. The Evangelical Lutheran Church in Denmark is also called the Church of Denmark: Den Danske Folkekirke, which literally means "the People's Church" or "the National Church". The Danish monarch is the head of the Church of Denmark. Most Danes belong to the Evangelical Church of the Augsburg Confession, which is subsidised by the government. In January 2018, 75.3\% of the population of Denmark were registered members of the Church of Denmark (Den Danske Folkekirke), the officially established church, which is Protestant in classification and Lutheran in orientation (Kirkeministeriet, 2018). The attendance, measured as a weekly participation, is only $3 \%$ (Bureau of Democracy, 2009).

Members of the Church of Denmark pay a church tax. The Church does not participate in political debates. The highest administrative body is the Ministry of the Church, also known as the Ministry of Ecclesiastical Affairs. Denmark proclaims the principle of cuius regio, eius religio ("whose realm, his religion"). Denmark remains a Protestant country, even despite the unrestricted presence of the Catholic Church during the last 100 years. However, it should be noted that Protestantism in Denmark is not so much a matter of faith and spirit, as it is a matter of culture. The Danish people consider religion to be a part of their national culture, the reason for which they are willing to pay the church tax, take care of the maintenance of churches and pastors, even if they rarely visit the institution itself. Why is this so?

Whereas the older generations simply followed moral principles, such as honesty, solidarity, responsibility and diligence, today's thirty-year-old Danes do not attach importance to these values, or religion as such - it is no longer of meaningful value to them. The new generation identify themselves not so much as Danes, but more as Europeans. A Danish person does not want to live according to Church rules anymore, opting instead 
for the approach of contemporary Europeans for whom the questions of faith and values are a private matter.

The typical participant in religious activities in Denmark is a woman (97\%), who is also a member of the Church (93\%). She is a university graduate $(86 \%)$, in most cases with a postgraduate degree (75\%). Socially, she belongs to the middle class and has the necessary resources to support her lifestyle choices (Vejrup Nielsen, 2015, p. 143). These participants, however, tend to have a general openness towards questions of spirituality. Most of them perceive themselves as "someone who believes", who either prays or meditates, at least occasionally. As argued by Marie Vejrup Nielsen (2015, pp. 142-143), the majority of the respondents were identified as occasional consumers of church activities in line with the typology of "cultural Christians". ${ }^{4}$ According to a research study by Phil Zuckerman (2009, p. 56), entitled Why are Danes and Swedes so irreligious?:

- Denmark has the lowest rates of church attendance in the world, only $12 \%$ of Danes attend church once a month and only $3 \%$ of Danes attend it at least once a week.

- Belief in life after death among Danes is as low as 30\% - one of the lowest in the world.

- 31\% of Danes believe in heaven, and $10 \%$ believe in hell.

- $7 \%$ of Danes believe that the Bible is the actual/literal word of God.

- $21 \%$ of Danes claim to pray at least several times in a given month.

- $15 \%$ of Danes claim to have ever had a "religious experience", while only $8 \%$ chose to describe their denomination as "Christian faith".

In March 2006, the Danish newspaper "Kristelig Dagblad" asked Danes what was the most important to them in relation to Easter: $58 \%$ said being with their family; $41 \%$ indicated getting a day off from work; $31 \%$ said the

${ }^{4} \mathrm{~A}$ study by Marie Vejrup Nielsen is cited here. The research project began with a pilot study of three churches in 2013 in Aarhus, the second largest city in Denmark. In the spring of 2014, a nationwide research project was developed and carried out. The provider survey was sent out to approximately 1200 parishes, obtaining a $65 \%$ response rate (776 responses). A high degree of consistency in the answers was found across different contexts and between the pilot study in the Aarhus area and the nationwide study, but the lack of response rate for the participant survey means that the findings cannot be used to claim universal patterns for specific target groups. The survey questionnaire for participants focused primarily on motivations for participation. The questions concerning motivations for participation were multiple-choice questions, and the responses are shown as percentages in order to identify the high and low scoring options. 
arrival of spring; while only $11 \%$ mentioned the death and resurrection of Jesus Christ.

Overall, only $51 \%$ of Danes claim to believe in a "personal God", while a mere $15 \%$ believe in a divine power. When asked "How important is God in your life?" (with 10 meaning "very important" and 1 meaning "not at all"), only $21 \%$ chose a number between 7 and 10 - again, among the lowest rates in the world (Zuckerman, 2009, p. 56). Let us now try to identify a number of possible reasons for this situation:

1. Stark and Finke (2000, p. 225) argue that the Lutheran Church has a "virtual monopoly" on religion because it is financed by the government. Other organisations do not have this kind of support. Stark and Finke claim that, when there are many different religions in a society - with none of them being state-subsidised - interest and involvement in religion will be high. Conversely, when there is only one dominant religion - one which is subsidised by the state - interest and involvement in religion will be low (Stark \& Finke, 2000, p. 225). In addition, its pastors are paid salaries and enjoy free medical care, which results in them having no motivation to solicit the faithful. ${ }^{5}$ This may be why the Danish National Lutheran Church sees little or no incentive to attract potential new members.

2. Another important factor affecting the level of religiosity among the Danish people is the issue of prosperity and security in Denmark. High earnings, social insurance for every citizen and generous social benefits all translate into a sense of safety, security and a high standard of living in Denmark, ultimately pushing religious needs and interests to the background (Lüchau \& Andersen, 2012, pp. 39-40). This is not an entirely new concept. Historically, people who experience difficulties or suffering in life have turned to religion for guidance and hope. Already in 1843, Karl Marx called religion "the opium of the people", a refuge for security, an illusory and false hope. Nevertheless, this interpretation seems to be mistaken.

\footnotetext{
${ }^{5}$ Lutheranism is the predominant religion in Denmark. Lutheranism has been consistently state-enforced and state-subsidised. Today, $83 \%$ of Danes continue to pay annual membership taxes/fees to keep their national church afloat. Thus, the "religious economy" of Denmark is one in which there is very little serious competition; the national Lutheran Church holds a virtual monopoly, albeit not an absolute monopoly, of course. About 4\% of Danes belong to independent, so-called "free" Christian churches (be they Baptist, Pentecostal, Methodist, Jehovah's Witnesses, etc.), another $1 \%$ of Danes are Catholic, and there also exist smaller religious movements such as the Baha'i Faith, Judaism, Scientology - not to mention the new and ever-growing influx of Islam.
} 
Religion arises instead from a certain lack of something, from human insufficiency. In the past, e.g. in the $19^{\text {th }}$ century, Denmark and Sweden were poor countries plagued by epidemics and hunger. However, a higher rate of religiousness was observed at that time. Donald Connery describes $19^{\text {th }}$-century Scandinavians as "a poverty-stricken mass". Over the course of the $20^{\text {th }}$ century, Denmark and Sweden became not only one of the wealthiest nations in the world, but also one of the most egalitarian (Connery, 1966, p. 6). Scandinavian countries boast the most well-developed welfare systems in the democratic world. Wealth in Scandinavia is shared throughout the population to an impressive degree, which is to say that the gap between the rich and the poor in Denmark and Sweden is smaller than in any other industrialised democracy. Accordingly, the high level of welfare these countries enjoy means that religion is becoming increasingly less important.

3. Working women. Callum Brown (2001, p. 10) argues that it was women who historically kept their children and husbands interested and involved in religion. Therefore, when they opted out of religion, their husbands and children followed suit (ibid.). It has long been known that women are inherently more religious than men, and it is up to them to maintain interest in the religion of their husbands and children, because women often teach prayers and take care of reading the Bible in the family. However, what can cause a change in women's religiosity? It can be argued that joining the labour force has a major impact. As researcher Ole Riis acknowledges, women in paid employment are less religious than women working at home (Riis, 1994, p. 122). ${ }^{6}$

4. Another reason for the poor condition of Christianity is that Denmark is a country of islands and peninsulas, strongly associated with nature, sagas and Edda, an aspect which will be discussed in more detail later in the article. One may ask why Christianity has never really taken root

${ }^{6}$ In the 1960 s, the vast majority of Danish women were engaged in unpaid domestic work as mothers and housewives. But over the course of the last four decades, there has been a big change in terms of women's involvement in the labour force. In 1960, over 800,000 Danish women worked at home as housewives. In 1969 , just over $43 \%$ of women worked outside the home in the paid labor force, but by 1990 that had increased to over $78 \%$. Today, the vast majority of Danish and Swedish women work outside the home (Møller, Andersen \& Stokholm, 2017). Thus, it is quite possible that the remarkably high degree of women in the paid workforce in Denmark helps account for the low levels of religiosity there. 
in Denmark. On the one hand, reaching back to history and following the situation of Christianity in Scandinavia from the $10^{\text {th }}$ century onwards, it seems that it has never really taken serious root anywhere in the Scandinavian world. Why? Mostly because the Scandinavians are islanders or the inhabitants of peninsulas, who live close to nature and whose spirituality is inseparably connected with it. In either case, the pre-Christian beliefs from poetic Edda, sagas and runic inscriptions point to their being rooted in nature and the search for transcendence within it. Therefore, Christianity will not take root in Denmark, while the neo-pagan movements are gaining traction in the same area. ${ }^{7}$ On the other hand, the reason for the poor condition of Christianity may be the fact that Denmark has never really had to defend the boundaries of its faith. Although this may now be challenged by Islam, one should not expect a defence-of-faith reaction, rather a certain form of rationalisation, justification or defence of European values, but not an increase in the Christian faith as a reaction to Islamisation.

5. The governing party in Denmark, namely the Social Democrats, have always been relatively anti-religious. This party seeks the removal of Lutheranism from schools, as well as the elimination of all religious images. Religious education in schools teaches a certain knowledge of religion as a whole, as well as the history of all religions. However, does this mean that religion is disappearing in Scandinavia and secularisation processes are well advanced? Not exactly, given that various forms of religion may be observed outside the Church.

\section{AN INVISIBLE RELIGION}

It is worth stressing that the whole of Europe has been undergoing secularisation for many years, including the Lutheran Church. The concept of secularisation was touched upon by the leading sociologists of religion, namely Émile Durkheim and Max Weber. Generally speaking, along with the advancement of societies, mainly through rationalisation and modernisation, religion loses its importance in all aspects of social life. This was first influenced by the rational disenchantment of the world (Weber's

\footnotetext{
${ }^{7}$ It is also worth noting that Scandinavia can be said to be geographically "separated" or "distanced" from what the outside influence. Historically, it meant that ideas arrived there with a slight delay and even without resistance, skepticism or suspicion.
} 
term). The disenchantment of religious life leads to a devaluation of special religious activities and valuing instead the activities of ordinary life. ${ }^{8}$ This devaluation is understood by Weber as a consequence of an alternative conception of rationality that develops as religions themselves go through an inner rationalisation, which tends to shift them into the irrational sphere. All this brings along lifestyle changes. Man becomes the centre of the world, and there is a departure from religious practices and the traditional role of the priest as the one who mediates in contact with God. It also prompts the creation of new religious movements. However, does it necessarily mean the disappearance of religious needs in man? The same question was posed by Thomas Luckmann, who studied changes in the religiosity of modern Western societies. Indeed, Luckmann showed that in the field of research on religiosity (defined as the sphere of the manifestation of religion), we are not dealing with the process of its dying, but rather its profound metamorphosis.

Luckmann argues that the focus should be shifted from secularisation to individualisation. He believes that individual religiosity loosens up, or completely breaks the connection with traditional religious institutions. Luckmann and his "invisible religion" (2006, p. 60). emphasise the growing role of the individual in contrast to the significance of the community. Individuals make decisions and act in respect of the principal value, namely life. Janusz Mariański (2009, p. 191) writes about the sacralisation of the individual autonomy. This new type of individualised religiosity, of a nonecclesiastical nature, is sometimes called invisible, hidden, analogical, postmodernist, indefinite, syncretic, dispersed, fluid, privatised, disharmonious, diverse religiosity. According to Luckmann, irreligion would mean denial of the human self and, consequently, challenge society itself. Man needs to transcend his biological nature, which is a certain anthropological constant. Religion, therefore, appears when a human being transcends a purely biological existence and enters the world of meanings. This is a transition from the so-called Big Transcendence to the Little Transcendence. According to Luckmann, religion is a necessity for an individual to become a human being as otherwise he would lose his personality. However, it can also be a private religion - one that moves from institutional dimensions to the inner world of an individual. For Luckmann (2003, p. 275),

\footnotetext{
${ }^{8}$ Charles Taylor speaks in his Sources of the Self that "affirmation of the ordinary" is a central motif of the emergence of modernity (1989, pp. 211-302).
} 
religion is the basic feature of the human condition and is a universal aspect of it. ${ }^{9}$ New religious forms include: personal experiences in the New Age, Zen meditation, reincarnation, magic, spiritualism, divination, astrology and horoscopes. The experience of little transcendence can also manifest itself in emancipation, self-realisation, coaching, or in various forms of psychotherapy or therapy. Thus, there is no question of the disappearance of religiosity in the present times, but rather of its transformation (privatisation or individualisation). Admittedly, in modern society, or even in post-modern societies, religion is becoming less important and people no longer refer to the sacred when making important decisions. However, religion has not gone from society, even if its manifestations have changed. Moreover, the definition of religion concerns its functions rather than its essence. ${ }^{10} \mathrm{It}$ is more difficult to describe whether something is a religion or not, which is why the definition of spirituality seems to be very helpful in describing modern phenomena which emerge and change very dynamically. Mariański even speaks about a certain "spiritual productivity" of contemporary culture.

\section{NEO-PAGANISM, OR A RETURN TO THE PAST AND ITS TRADITIONS}

Neo-paganism belongs to the so-called new religiosity. It is an idea of the return and reconstruction of pre-Christian European traditions. Although the first concepts of this return date back to Romanticism, it was only the $20^{\text {th }}$ century that brought about the revival of this movement in Europe.

Speaking of neo-paganism in Denmark, I refer to the Forn Siðr ${ }^{11}$ movement, which is also the name of the largest organisation within Asatru (literally "faith in the Asses" gods). Forn Sidr is an old custom within Danish tradition whose goal is to reconstruct the religion of northern Germans, namely Vikings from before the period of Christianisation of Denmark

${ }_{9}^{9}$ According to Luckmann, religion is not a transient phase in the evolution of the human species, but a universal aspect of the conditio humana (2003, p. 275).

${ }^{10}$ Functional definitions define what religion does in society, how to deal with problems, social integration, give meaning to reality, and assume that religion is a human phenomenon.

${ }^{11}$ Official website of Forn Siðr: http://fornsidr.dk/. 
(965 AD). ${ }^{12}$ According to Arkadiusz Sołtysiak, a Polish researcher of neo-paganism, this religion is "a faithful reconstruction of early-medieval Scandinavian beliefs, based on scientific criticism of literary sources - reborn and adapted to the contemporary reality of the Scandinaviansituation" (1999, p. 243). There is no extensive organisation in Asatru. The movement was officially founded in 1997 in Odense with its founders wanting to organise this movement in Denmark based on the Icelandic model. Currently, the movement has 1,000 members in Denmark, while 100 people are members of other organisations associated with the idea of returning to the Nordic religion from before the Christianisation of Denmark, based on sagas and poetic Edda. It is an apolitical organisation that is very active in the media (press, radio, TV, internet). The proponents of the movement strive to raise social awareness about the old-custom beliefs of Denmark. According to the content of Forn Siðr's declaration of faith we can say that they believe in the same gods who once gave their ancestors meaning and helped them, AEsir-Vanir, and they trust them. Each individual divine figure represents an aspect of reality that cannot be denied. They also recognise the existence of elves, ghosts, giants, the Sun and the Moon. Everything is a part - and a symbol - of our multi-faceted world. The Yggdrasil Ash Tree is the centre of the world, where the wise Norns controlling the past, present and future, sit and spin our destinies. The contact between the divine powers and the individual person is given to anyone who is looking for it, in its own, unique way. They honour their ancestors and give greetings to those, who will come after us. They believe that mankind, animals, nature and holy places are full of both life and spirit. They treat the world around us with respect and consideration (Forn Siðr, 2016).

This text emphasises the individualism of faith where free space is left to interpret the figures of the deities. Gods are generally understood as symbols (Asatru is a symbol that serves human development). On the one hand, gods are interpreted as forces of nature and the other as archetypes, which represent separate aspects of human existence.

12 In Scandinavia, we observe a strong attachment to pagan gods and visions of the world presented in mythology, strong relationships with the natural world, nature which is harsh but also nursing and feeding what in that climate is particularly meaningful and important. This is why one may observe a return towards neo-paganism in the last decade and the dynamic growth this organisation in Denmark: Asatru (Danish old customs). They strive hard for institutionalisation and for the denial of Christianity. 
In article about the movement of Asatru, Michalina Biel quotes the statement of a member of this movement:

The word "believe" is too strong for me, but it is something that makes sense to me. I do not believe in Thor riding in the sky, but I believe that his picture is what makes sense in explaining the enormous energy released in a storm. I do not believe that gods exist as people, but that they are very strong images that make sense in individual humans' life context. That suits me, it's like coming home, this makes sense to me (Biel 2009, p. 39).

Freedom of interpretation and trust in one's own feelings may be observed in this statement. Odin, for instance, who is customarily described as the god of war and warriors, is also perceived as the personification of wisdom, magic, poetry, death, the discoverer of the runic script. One of the people belonging to Forn Siðr perceives Odin as an extremely strong image, a personification of inner wisdom, ecstasy, death, struggle and magic, everything that is inexplicable in wisdom. An individual who meditates or prays to these gods, assimilates the same kinds of values in themselves, which the gods represent as archetypes. Joining the gods is equivalent to connecting with the source, while the way the source is interpreted and the way it is understood is different. ${ }^{13}$

The main ethical principle is honour, understood, on the one hand, as being faithful to the gods, and on the other hand, as a responsibility for oneself and for one's actions. One must emphasise that the gods known from Edda make the same mistakes as ordinary people. They are not ethical role models - they are neither good nor bad. It is man who decides what they mean to him. Members of the Asatru movement criticise Christian ethics for restrictions in the sexual sphere, rejecting the notion

${ }^{13}$ Pagan beliefs created many gods, deities, good and bad beings - similar to people, with similar vices, passions etc. - gods such as Thor or Freja were like people and therefore close to them. The rich reservoir of characters provided a broad spectrum of references - everyone could choose someone from this pantheon, while some gods appeal in every aspect of life. Christianity did not offer such diversity - it showed "only" one God, indeed one with his human incarnation, but one after all. Perhaps he was also "weak", because he was defeated by death. After three days, he overcame death by resurrection, but before this happened, he suffered and was humiliated. Perhaps this is why Scandinavians were afraid of humiliation and weakness, while Christianity did not have a chance to take root not only in Denmark. It can be said that the Danes are a proud and detached nation as they are descendants of the Vikings. This issue remains open. 
of sin and eternal punishment. It is a religion that calls for self-confidence and refuses to follow social norms and principles. Another important element is the honour for the memory of one's ancestors - what lives on after death is one's deeds during one's lifetime. Moreover, family values are emphasised.

This religion is a form of reconstructionism. The reconstruction here is based on the revival of an old religion in the conditions of the modern world, providing sensible answers to the needs of contemporary man. It is an attempt to dig out the old roots in order to grow a new tree. Neopagans feel a strong need to build identity, create bonds and cultivate tradition. It is through memory that this religious group finds its sense of identification. Rituals are employed to recall a past that gives meaning to the present and creates a religious thread. On the one hand, we can point to the rejection of the radical authority of tradition; on the other, to the need to refer to it. Society must maintain the continuity of tradition in order to exist, as argued by Danièle Hervieu-Léger in Religion as a Chain of Memory. According to Hervieu-Léger (1999, p. 142), religion is one of the forms of belief which is characterised by legitimising the exclusiveness of reference to tradition. However, for such reference to be religious, the belief must refer to some past and include the perspective of the future. This past may be either real or made up, as long as the religion remains a tool for creating and maintaining continuity, which is a collection of pictures, images, knowledge and behavioural patterns in the name of binding the past and the future. The essence of tradition is not that it is a bridge between the past and the present, but that it awards a transcendent authority to the past (ibid., p. 125).

\section{CONCLUSIONS}

Not only Scandinavia, but all of Europe is subject to secularisation processes, as a result of which the role of religion (Christianity) is being reduced or eliminated from social life. However, the need for transcendence has yet to disappear in man. In addition, it must be emphasised that the realisation of this need is an expression of human freedom. As has been demonstrated in this article, this need manifests itself in the return to neo-paganism, the religion of reconstructing the beliefs of ancient and medieval Germans, which died out as a result of Christianisation in the $10^{\text {th }}$ century. The return 
to neo-paganism is an attempt to overcome the feeling of lack of roots what is so typical of the Danish people. On the other hand, the need for transcendence is realised via spirituality, which is expressed in self-directedness. ${ }^{14}$ Both of these directions are a choice of freedom and fulfilment of the need to look for meaning and identity in a dynamically changing world.

\section{BIBLIOGRAPHY}

Biel, M. (2009). Forn Siđr - Ásatrú w Danii. Ex Nihilo. 2(2), 34-60.

Brown, C. (2001). The Death of Christian Britain. New York, NY: Routledge.

Bureau of Democracy, Human Rights, and Labor. (2009, October 26). International Religious Freedom Report 2009. Retrieved October 18, 2018, from https://www.state.gov/j/drl/rls/ irf/2009/127307.htm

Connery, D. (1966). The Scandinavians. New York: Simon and Schuster.

Forn Siðr. (2016). Grundlag. Retrieved October 18, 2018, from http://www.fornsidr.dk/index. php/om-forn-sidhr/7-grundlag

Hervieu-Léger, D. (1999). Religia jako pamięć (M. Bielawska, Trans.). Kraków: Zakład Wydawniczy "Nomos".

Kirkeministeriet (2018). Folkekirkens medlemstal. Retrieved October 18, 2018, from http:// www.km.dk/folkekirken/kirkestatistik/folkekirkens-medlemstal/

Luckmann, T. (2003). Transformations of Religion and Morality in Modern Europe. Social Compass, 50(3), 269-276.

Luckmann, T. (2006). Niewidzialna religia. Problem religii we współczesnym społeczeństwie (L. Bluszcz, Trans.). Kraków: Zakład Wydawniczy „Nomos”.

Lüchau, P., \& Andersen, P. B. (2012). Socio-economic factors behind disaffiliation from the Danish National Church. Nordic Journal of Religion and Society, 25(1), 27-45. Retrieved from http://tapir.pdc.no/pdf/NJRS/2012/2012-01-2.pdf

Mariański, J. (2009). „Niewidzialna religia” w badaniach socjologicznych. Studia Płockie. 37, 191-209.

Møller, M., Andersen, M., \& Stokholm, K. (2017). The confederation of Danish Employers' Vision for the Future of the EU. Retrieved October 18, 2018, from http://www.da.dk/bilag/ A4_Rapport_DAs_bud_p\%E5_fremtidens_EU_2017_engelsk_web.pdf

Riis, O. (1994). Patterns of secularization in Scandinavia. In T. Pettersson \& O. Riis (Eds.), Scandinavian Values: Religion and Morality in the Nordic Countries (pp. 99-128). Uppsala: ACTA Universitatis Upsaliensis.

${ }^{14}$ The disappearance of the need for transcendence (although I would rather refer to it as "dimming") and turning towards oneself, seeking an inner sense that is subordinated to the principal goal: self-development. Hence, the great popularity of workshops on developing personal potential or interest in coaching. Man has become a goal for himself but also, to borrow from Protagoras, he has become the measure of all things. The whole of Europe, including Poland, is being subjected to this process of secularisation. 
Skowronek, K., \& Pasek, Z. (2013). Nowa duchowość w kulturze popularnej. Studia tekstologiczne. Kraków: Wydawnictwo LIBRON.

Socha, P. M. (2014). Przemiana. W stronę teorii duchowości. Kraków: Zakład Wydawniczy "Nomos".

Sołtysiak, A. (1999). Ścieżka Ásatrú. The Peculiarity of Man. 4, 241-294.

Stark, R., \& Finke, R. (2000). Acts of Faith: Explaining the Humans Side of Religion. Berkeley, CA: University of California Press.

Taylor, Ch. (1989). Sources of the Self. The Making of Modern Identity. Cambridge: Cambridge University Press.

Vejrup Nielsen, M. (2015). Changing patterns? Occasional Consumers of New Activities in Old Churches. Nordic Journal of Religion and Society, 28(2), 137-153. Retrieved from http:// tapir.pdc.no/pdf/NJRS/2015/2015-02-3.pdf

Zuckerman, P. (2009). Why are Danes and Swedes so irreligious? Nordic Journal of Religion and Society, 22(1), 55-69. Retrieved from http://tapir.pdc.no/pdf/NJRS/2009/2009-01-4.pdf 